\title{
Perancangan Aplikasi Multimedia untuk Pembelajaran Anatomi Tubuh Manusia untuk Sekolah Dasar
}

\author{
Dini Indriyani Putri ${ }^{1)}$, R. Rizal Isnanto ${ }^{2)}$, Kurniawan Teguh Martono ${ }^{2)}$ \\ Program Studi Sistem Komputer Fakultas Teknik Universitas Diponegoro \\ Jalan Prof. Sudharto, Tembalang, Semarang, Indonesia \\ dindriyanip@student.undip.ac.id
}

\begin{abstract}
Abstrak - Pada pembelajaran anatomi tubuh manusia dibutuhkan metode dan media yang baru agar dapat meningkatkan semangat dan minat siswa dalam mempelajari anatomi tubuh manusia. Hal ini dikarenakan metode yang umum digunakan di sekolah-sekolah masih menggunakan metode guru menerangkan dan siswa mendengarkan, serta buku pelajaran yang digunakan minim akan ilustrasi sehingga siswa kurang aktif dan mudah cepat jenuh dengan materi yang diterangkan di kelas. Berdasarkan permasalahan tersebut dibangun sebuah Aplikasi Multimedia Pembelajaran Anatomi Tubuh Manusia berbasis desktop yang diharapkan dapat mendukung proses pembelajaran di sekolah.

Tahap-tahap yang dilalui dalam membangun aplikasi multimedia pembelajaran ini adalah mempelajari studi pustaka, mewawancari narasumber, merancang aplikasi, pembuatan aplikasi dan terakhir tahap pengujian. Aplikasi ini dibangun menggunakan Adobe Flash Professional, Adobe Illustrator dan Adobe Photoshop. Metode pengembangan mutimedia yang digunakan adalah Multimedia Development Life Cycle (MDLC). Untuk metode pengujian aplikasi menggunakan metode Black Box Test.

Aplikasi multimedia pembelajaran Anatomi Tubuh Manusia sebagai media pembelajaran interaktif untuk sekolah dasar, sudah berhasil dirancang dan dibangun menggunakan Adobe Flash Professional. Hasil dari pengujian Kotak Hitam pada aplikasi ini adalah fungsi dalam setiap menu dan tombol telah berjalan dengan semestinya.
\end{abstract}

Kata kunci : Multimedia Pembelajaran, Adobe Flash Professional, Multimedia Development Life Cycle (MDLC), Anatomi Tubuh Manusia.

\section{PENDAHULUAN}

Kegiatan belajar dapat dilakukan oleh siapa saja, terutama dilakukan oleh seorang yang masih berstatus sebagai seorang pelajar. Untuk meningkatkan keberhasilan belajar, setiap siswa memiliki metode yang berbeda-beda. Salah satu metode pembelajaran yang menarik sehingga dapat menambah minat siswa adalah dengan memanfaatkan multimedia. Aplikasi multimedia dalam metode pembelajaran cukup menarik karena berisi gambar berwana, suara bahkan animasi. Belajar menggunakan multimedia membuat seorang siswa tidak bergantung besar dengan adanya pengajar. Dimana seorang pengajar atau guru, dosen hanya berperan sebagai mediator dan fasilitator yang membantu proses belajar siswa atau mahasiswa saja agar berjalan dengan baik ${ }^{[1]}$.
Mata Pelajaran Ilmu Pengetahuan Alam (IPA) khususnya rangka dan organ tubuh manusia akan lebih memberikan kesan kepada siswa jika metode pembelajaran yang disampaikan tidak hanya berpusat pada teori, karena dengan metode pembelajaran yang demikian maka siswa akan merasa jenuh dan kurang tertarik untuk mempelajarinya, seharusnya guru tidak hanya menyampaikan materi berupa teori, namun menunjukkan perangkat secara nyata yang terkait dengan materi tersebut atau menggunakan media pembelajaran interaktif yang dapat menyimulasikan perangkat.

Multimedia interaktif dapat diartikan sebagai kombinasi berbagai unsur media yang terdiri dari teks, grafis, foto, animasi, video, dan suara yang disajikan secara interaktif dalam media pembelajaran ${ }^{[4]}$. Dapat dikatakan multimedia dapat membawa perubahan dalam proses pembelajaran, yaitu dari model pembelajaran pasif menjadi model pembelajaran aktif ${ }^{[5]}$. Sehingga, media pembelajaran sebagai pendamping dengan menggunakan multimedia akan sangat membantu dalam proses pembelajaran karena media dapat memberikan pengalaman visual kepada siswa dalam rangka mendorong motivasi belajar, memperjelas, dan mempermudah konsep yang kompleks dan abstrak menjadi lebih sederhana, konkrit, serta mudah dipahami ${ }^{[6]}$.

\section{LANDASAN TEORI}

A. Materi Ilmu Pengetahuan Alam mengenai Anatomi Tubuh Manusia

Anatomi berasal dari Bahasa Yunani yang terdiri atau dua kata yaitu ana dan tomos. Dimana ana memiliki arti memisahkan atau menguraikan dan tomos memiliki arti memotong-motong, sehingga anatomi dapat diartikan menguraikan dan memotong. Kesimpulannya, anatomi adalah ilmu yang mempelajari bentuk dan susunan tubuh yang diperoleh dengan cara menguraikan tubuh melalui potonganpotongan bagian tubuh dan bagaimana hubungan organ tubuh satu dengan yang lain ${ }^{[10]}$.

1. Rangka

Kerangka manusia merupakan kerangka dalam, yang tersusun dari tulang keras (osteon) dan tulang rawan (kartilago).

\section{Sistem Indera}

Sistem indera pada tubuh manusia merupakan bagianbagian tubuh yang secara langsung menerima rangsangan atau untuk mengetahui keadaaan yang ada dari lingkungan luar. Alat indera manusia sering disebut panca indra, karena terdiri dari lima (5) indra yaitu indra penglihat (mata), indra 
pendengar (telinga), indra pengecap (lidah), indra pembau/pencium (hidung), dan indra peraba (kulit).

3. Organ Dalam

Di dalam organ dalam tubuh manusia terdapat dua sistem yaitu sistem pernapasan dan sistem pencernaan. Sistem pernapasan, dimana pernapasan memiliki fungsi memasukkan oksigen dari udara yang akan digunakan untuk mengoksidasi makanan serta mengeluarkan sisa hasil oksidasi, yaitu karbon dioksida. Dan sistem pencernaan merupakan sistem yang memproses untuk mengubah makanan dan menyerap sari makanan yang berupa nutrisi-nutrisi yang dibutuhkan oleh tubuh.

\section{B. Media Pembelajaran}

Media pembelajaran merupakan segala sesuatu yang dapat digunakan untuk menyalurkan pesan dari pengirim ke penerima sehingga dapat merangsang pikiran, perasaan, perhatian dan minat peserta didik sedemikian rupa sehingga mempertinggi proses belajar ${ }^{[14]}$.

\section{Multimedia Pembelajaran Interaktif}

Pembelajaran diartikan sebagai proses penciptaan lingkungan yang memungkinkan terjadinya proses belajar. Belajar dalam pengertian aktivitas mental siswa dalam berinteraksi dengan lingkungan yang menghasilkan perubahan perilaku yang bersifat relatif konstan. Dengan demikian aspek yang menjadi penting dalam aktivitas belajar adalah lingkungan. Bagaimana lingkungan diciptakan dengan menata unsur-unsurnya sehingga dapat mengubah perilaku siswa. Dari uraian di atas, disimpulkan bahwa multimedia pembelajaran dapat diartikan sebagai aplikasi multimedia yang digunakan dalam proses pembelajaran ${ }^{[13]}$.

\section{Adobe Flash}

Adobe Flash (dulu dikenal dengan Macromedia Flash) merupakan platform multimedia yang awalnya dikembangkan oleh Macromedia, sekarang dikembangkan dan didistribusikan oleh Adobe System ${ }^{[18]}$. Adobe Flash CS5 merupakan sebuah program yang ditujukan kepada para desainer tau programmer yang merancang animasi untuk pembuatan sebuah halaman web, pembuatan game interaktif, proses pembelajaran, pembuatan film kartun dan dapat digunakan untuk membangun sebuah aplikasi yang bernilai tinggi. Keunikan dan kelebihan adobe flash ini adalah program animasi yang berbasis vektor yang dapat menghasilkan file yang berukuran kecil sehingga mudah diakses ${ }^{[18]}$.

\section{E. Multimedia Development Life Cycle (MDLC)}

Metodologi yang digunakan adalah Multimedia Development Life Cycle (MDLC) yang bersumber dari Luther dan sudah dimodifikasi oleh Sutopo. Metodologi pengembangan multimedia tersebut terdiri dari enam tahap, yaitu konsep (concept), perancangan (design), pengumpulan materi (material collecting), pembuatan (assembly), pengujian (testing), dan distribusi (distribution). Keenam tahap ini tidak harus berurutan dalam prakteknya, tahap-tahap tersebut dapat saling bertukar posisi. Meskipun begitu, tahap konsep memang harus menjadi hal yang pertama kali dikerjakan ${ }^{[8]}$. Tahapan pengembangan multimedia pada metodologi MDLC ditunjukkan pada Gambar 1

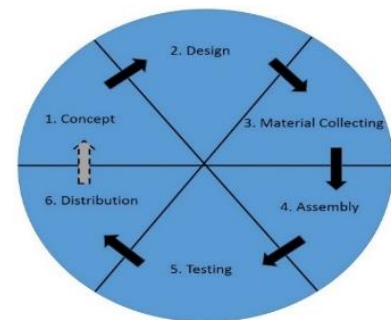

Gambar 1 Tahapan pengembangan multimedia

\section{F. Pengujian Kotak Hitam}

Pada tahap ini dilakukan pengujian dari aplikasi pembelajaran yang telah dibuat, apakah aplikasi pembelajaran sudah sesuai dengan perancangan dan kebutuhan atau belum. Dalam pengujian ini dilakukan per menu, bukan setelah semua aplikasi selesai. Hal ini akan mempermudah dalam deteksi kesalahan karena ketika terdapat kesalahan dari suatu menu maka dapat langsung diperbaiki. Pengujian pada pembuatan aplikasi pembelajaran ini menggunakan pengujian black box testing yang berguna untuk menguji fungsionalitas suatu program yang akan dibahas pada bab selanjutnya.

\section{PERANCANGAN SISTEM}

\section{A. Konsep (Concept)}

Media pembelajaran yang dibuat mempunyai konsep bagaimana menyajikan sebuah materi pembelajaran dalam bentuk yang interaktif yang dapat membantu siswa dalam belajar. Dengan dibuatnya media pembelajaran interaktif, diharapkan dapat meningkatkan minat dan membantu siswa dalam belajar. Materi yang disampaikan pada aplikasi media pembelajaran ini adalah materi Ilmu Pengetahuan Alam (IPA) khususnya materi anatomi tubuh manusia untuk sekolah dasar.

B. Perancangan (Design)

Tahap perancangan aplikasi pendamping pembelajaran dimulai dengan membuat rancangan aplikasi melalui struktur menu aplikasi untuk halaman utama, perancangan menggunakan use case diagram, sequence diagram dan Activity Diagram. Kemudian membuat perancangan antarmuka tampilan Aplikasi Pembelajaran Anatomi Tubuh Manusia ini.

\section{Perancangan Aplikasi dengan Use Case Diagram}

Use case diagram digunakan untuk memodelkan dan menyatakan unit fungsi atau layanan yang disediakan oleh sistem ke pengguna. Dalam aplikasi Pembelajaran Anatomi tubuh manusia ini hanya ada satu pengguna yaitu user. User dapat berinteraksi dan dapat melakukan tindakan ke dalam sistem yang sudah memiliki skenario didalamnya. Berikut adalah use case diagram dari Aplikasi Pembelajaran Anatomi Tubuh Manusia yang telah ditunjukkan pada Gambar 2. 


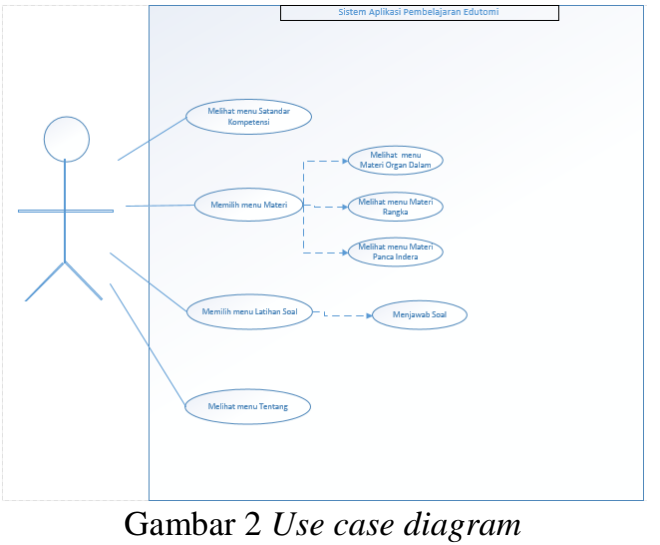

2. Perancangan Aplikasi dengan Sequence Diagram

Sequence diagram digunakan untuk menggambarkan interaksi antar objek di dalam dan di sekitar sistem yang berupa pesan yang digambarkan terhadap waktu. Sequence diagram terdiri antara dimensi vertikal (waktu) dan dimensi horizontal (objek-objek yang terkait). Berikut adalah sequence diagram dari diagram use case yang digunakan pada Aplikasi Pembelajaran Anatomi Tubuh Manusia.

Sequence diagram memilih menu Standar Kompetensi ditujukkan pada Gambar 3.

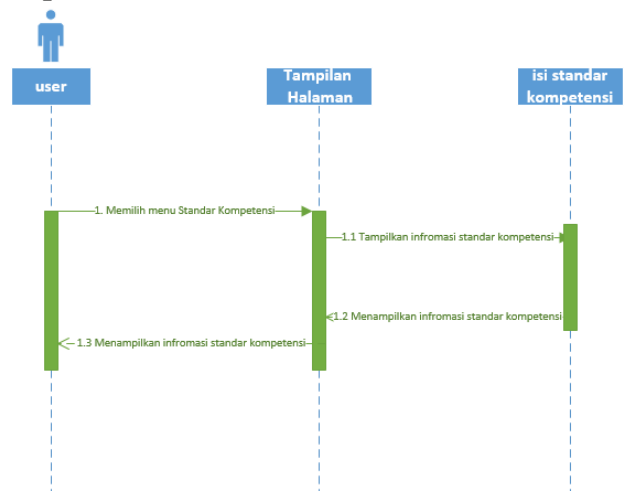

Gambar 3 Sequence diagram memilih menu Standar Kompetensi

Sequence diagram memilih menu Materi ditujukkan pada Gambar 4.

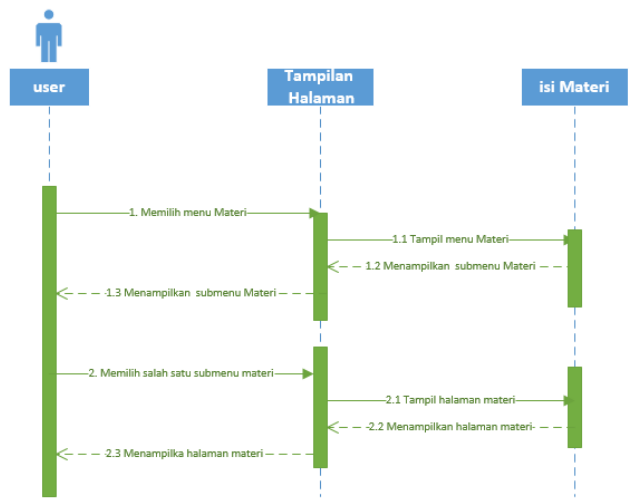

Gambar 4 Sequence diagram memilih menu Materi
Sequence diagram memilih menu Latihan Soal ditujukkan pada Gambar 5.

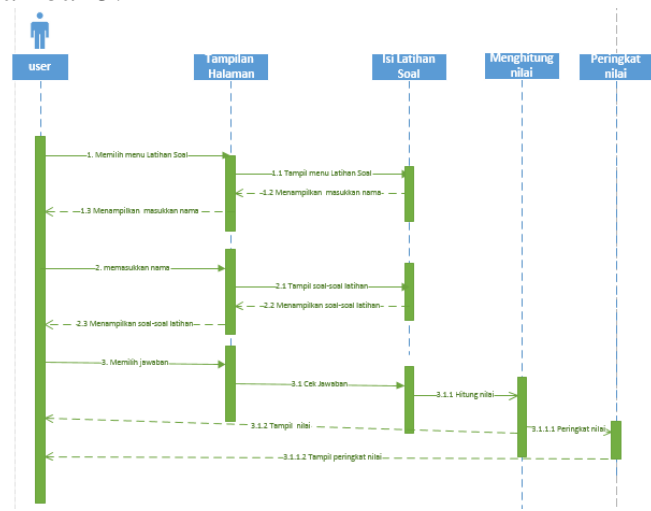

Gambar 5 Sequence diagram memilih menu Latihan Soal

Sequence diagram memilih menu Tentang ditujukkan pada Gambar 6.

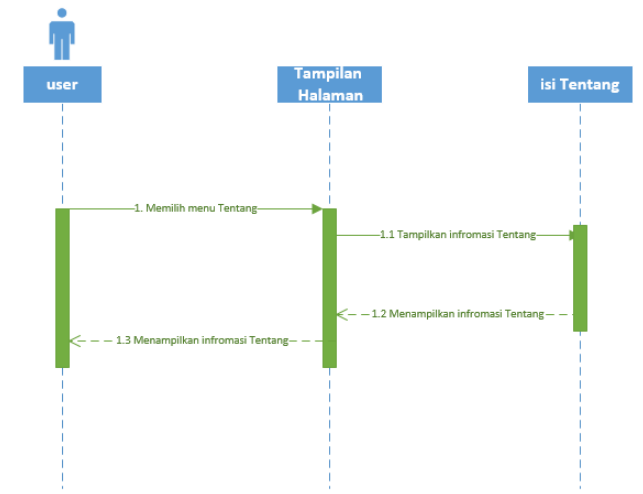

Gambar 6 Sequence diagram memilih menu Tentang

3. Perancangan Aplikasi dengan Activity Diagram

Activity Diagram digunakan untuk menjelaskan tentang urutan aktivitas dalam aplikasi Anatomi Tubuh Manusia. Dalam activity diagram terdapat beberapa komponen yaitu Action state merepresentasikan sebuah proses yang dilakukan oleh sebuah elemen. Action state inisial merupakan action pertama yang dijalankan dalam diagram aktivitas. Action state final: action terakhir yang dijalankan dalam diagram aktivitas. Swimlane merupakan daerah visual dalam diagram aktivitas yang menghindikasikan elemen yang bertanggung jawab terhadap action state dalam daerah tersebut. Pengambilan keputusan dilakukan dengan memilih salah satu control-flow sesuai dengan kondisi yang diinginkan. Concurrency memilih beberapa transisi sekaligus.

Terdapat empat Activity Diagram yang akan ditunjukkan untuk menggambarkan empat fungsi pada aplikasi ini, yaitu Activity Diagram standar kompetensi, Activity Diagram materi, Activity Diagram latihan soal dan Activity Diagram checklist tentang.

Pada Gambar 7 yaitu Activity Diagram yang menggambarkan diagram aktifitas Standar Kompetensi pada aplikasi Anatomi Tubuh Manusia. 


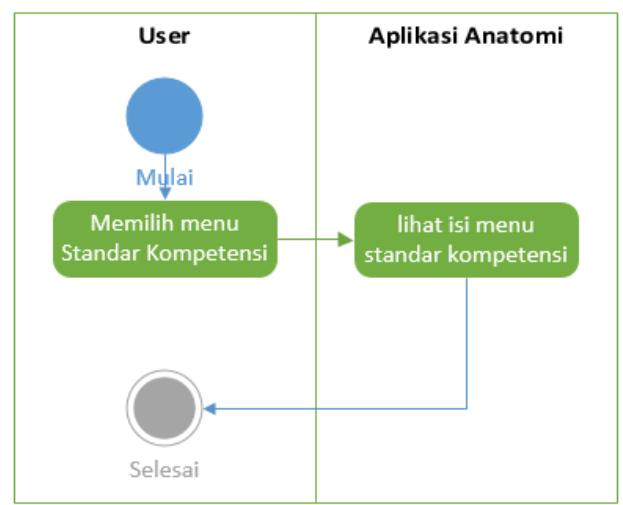

Gambar 7 Activity Diagram standar kompetensi

Pada Gambar 3.7 menunjukkan dimana proses yang terjadi ketika User memilih Menu Standar Kompetensi. Proses pertama adalah User mengklik tombol Menu Standar Kompetensi pada menu utama. Kemudian halaman akan berganti ke halaman selanjutnya, yaitu halaman isi standar kompetensi.

Pada Gambar 8 yaitu Activity Diagram yang menggambarkan diagram aktifitas Materi pada aplikasi Anatomi Tubuh Manusia.

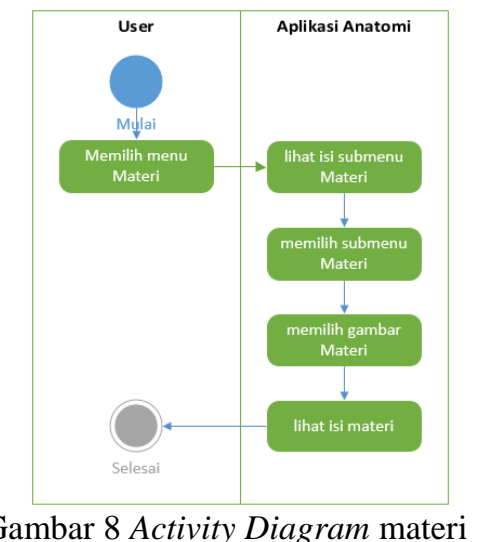

Untuk Gambar 8 menggambarkan bagaimana proses yang terjadi ketika User memilih Menu Materi. Proses pertama adalah User mengklik Menu Materi pada halaman utama. Setelah masuk ke halaman selanjutnya User mendapati ada tiga submenu Materi, kemudian User memilih salah satu submenu. Setelah masuk ke halaman selanjutnya terdapat gambar Materi, dan User dapat memilih salah satu bagian gambar dengan mengklik salah satu bagian gambar. Setelah bagian gambar yang diinginkan diklik oleh User, maka akan muncul halaman yang berisi penjelasan tentang bagian gambar tersebut.

Pada Gambar 9 yaitu Activity Diagram yang menggambarkan diagram aktifitas Latihan Soal pada aplikasi Anatomi Tubuh Manusia.

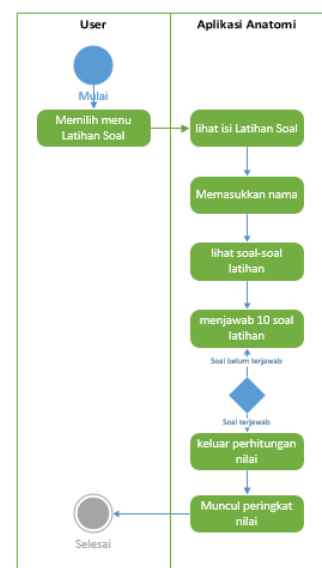

Gambar 9 Activity Diagram latihan soal

Aktifitas yang terjadi pada Gambar 9 adalah menggambarkan proses yang terjadi ketika User memilih Menu Latihan Soal. Proses pertama adalah User mengklik Menu Latihan Soal pada halaman utama. Selanjutnya User akan melihat halaman berikutnya yang berisi masukkan nama. User akan memasukkan nama dan mengklik tombol Mulai. Selanjutnya akan ditampilkan soal-soal latihan dan User harus menjawab soal tersebut. Setelah semua soal dijawab User makan akan ada proses perhitungan nilai, akan muncul jumlah salah, benar dan nilai. Setelah itu akan muncul peringkat nilai, dengan begitu User dapat melihat peringkat.

Pada Gambar 10 yaitu Activity Diagram yang menggambarkan diagram aktifitas Tentang ada aplikasi Anatomi Tubuh Manusia.

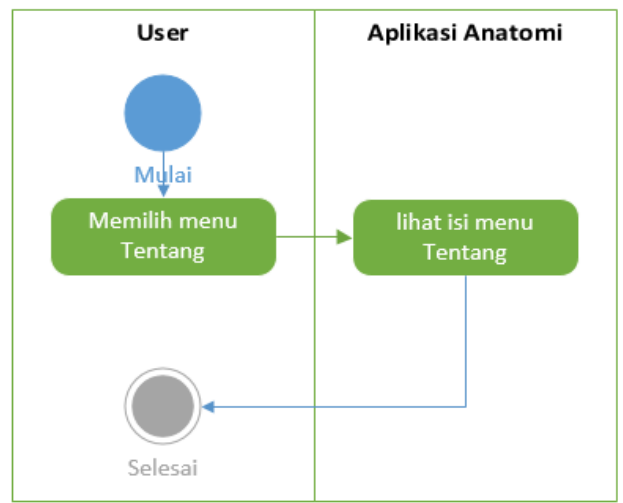

Gambar 10 Activity Diagram tentang

Pada Gambar 3.10 menunjukkan dimana proses yang terjadi ketika User memilih Menu Tentang. Proses pertama adalah User mengklik tombol Menu Tentang pada menu utama. Kemudian halaman akan berganti ke halaman selanjutnya, yaitu halaman isi Tentang.

\section{Perancangan Antar Muka}

Setelah pembuatan bagan perancangan aplikasi dan bagan alir, selanjutnya dibuat desain tampilan untuk setiap halaman menu atau isi menu. Desain tampilan menu awal aplikasi ditunjukkan oleh Gambar 11. 


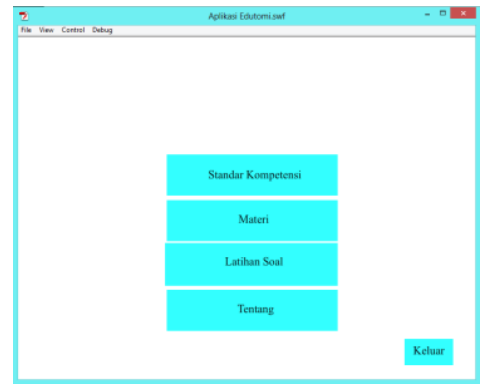

Gambar 11 Tampilan menu awal

Desain tampilan isi menu Standar Kompetensi ditunjukkan oleh Gambar 12.

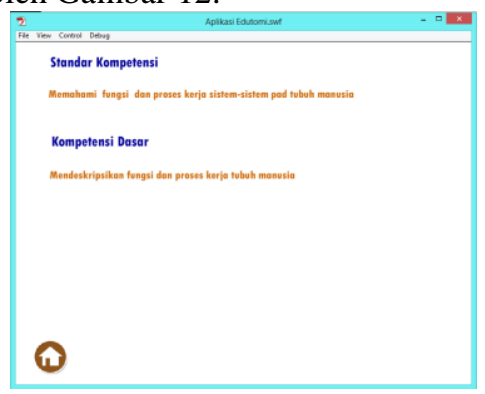

Gambar 12 Tampilan isi menu Standar Kompetensi

Di dalam menu Materi terdapat 2 bagian yaitu Rangka dan Organ. Desain tampilan menu Materi ditunjukkan oleh Gambar 13.

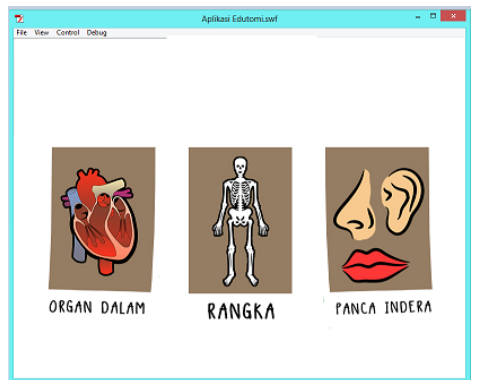

Gambar 13 Tampilan menu Materi

Desain tampilan menu Panca Indera ditunjukkan oleh Gambar 14.

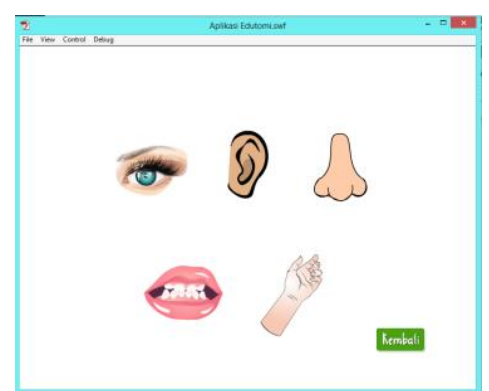

Gambar 14 Tampilan menu Materi Panca Indera

Desain tampilan isi Materi Panca Indera ditunjukkan oleh Gambar 15.

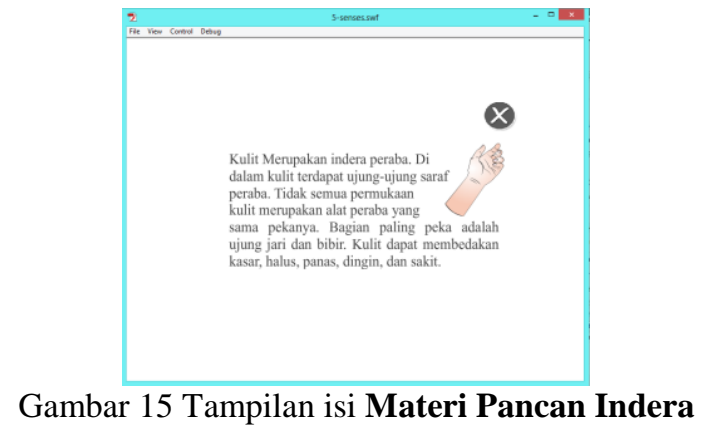

Desain tampilan awal memulai Latihan Soal ditunjukkan oleh Gambar 16.

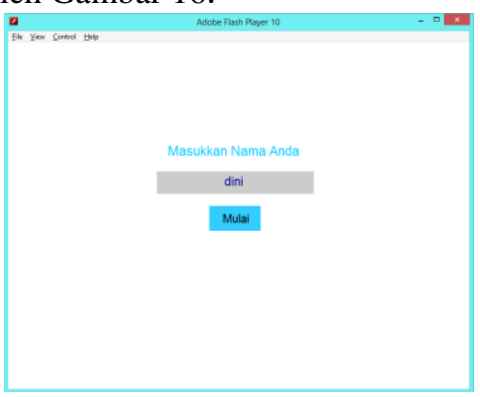

Gambar 16 Tampilan awal menu Latihan Soal

Desain tampilan soal ditunjukkan oleh Gambar 17.

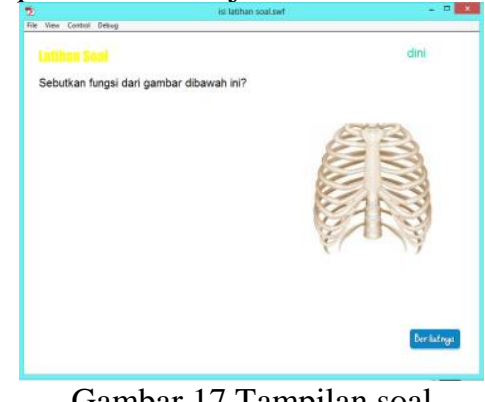

Desain tampilan nilai Latihan Soal ditunjukkan oleh Gambar 18.

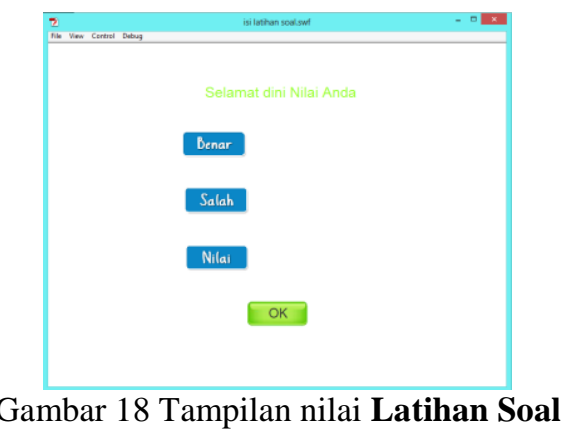

Desain tampilan peringkat nilai tertinggi pada hasil Latihan Soal ditunjukkan oleh Gambar 19. 


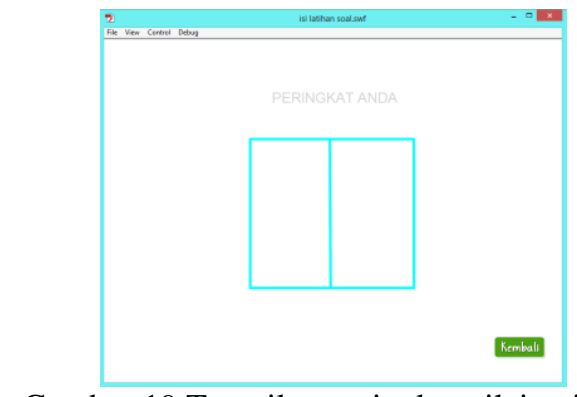

Gambar 19 Tampilan peringkat nilai tetinggi hasil Latihan Soal

Gambar 20

Desain tampilan menu Tentang ditunjukkan oleh

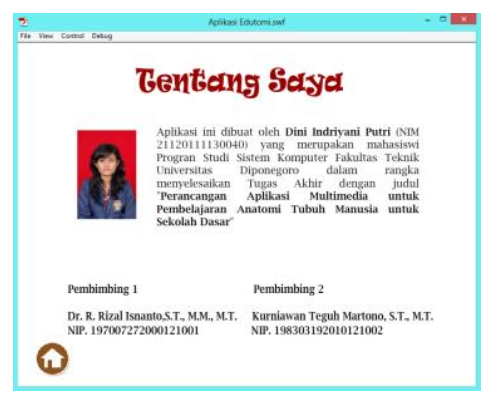

Gambar 20 Tampilan menu Tentang

\section{HASil PENELITIAN DAN PEMBAHASAN}

\section{A. HASIL PENELITIAN}

Berikut merupakan tampilan aplikasi yang dibuat.

1. Tampilan menu awal

Aplikasi ini mempunyai 4 menu yang berisi menu Standar Kompetensi, menu Materi, menu Latihan Soal dan menu Tentang. Tampilan menu awal ditunjukkan oleh Gambar 21.

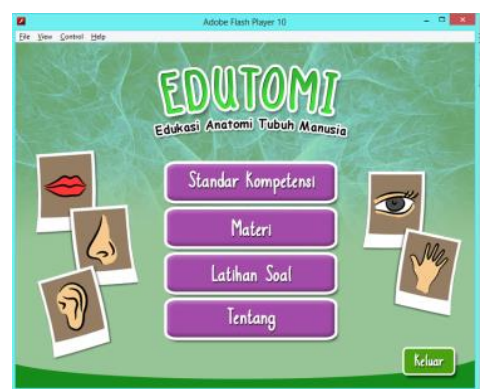

Gambar 21 Tampilan menu awal

\section{Tampilan menu Standar Kompetensi}

Di menu ini berisi standar kompetensi dan kompetensi dasar dari materi yang dikemas dalam aplikasi. Standar Kompetensi dan Kompetensi Dasar yang ada sesuai dengan kurikulum yang ada di Sekolah Dasar.

Tampilan isi menu Standar Kompetensi ditunjukkan oleh Gambar 22.

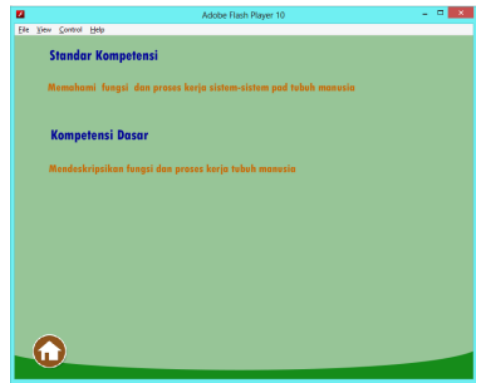

Gambar 23 Tampilan isi menu Standar Kompetensi 3. Tampilan menu Materi

Materi Edutomi ini membahas 4 bagian, yaitu organ dalam, rangka dan panca indera. Ketiga bagian materi tersebut dikemas dengan tampilan yang hampir sama. Untuk melihat isi materinya harus mengklik kursor pada bagian menu Materi, klik pada organ dalam untuk melihat materi organ dalam, rangka untuk materi rangka, panca indera untuk materi panca indera. Tampilan menu Materi ditunjukkan oleh Gambar 24.

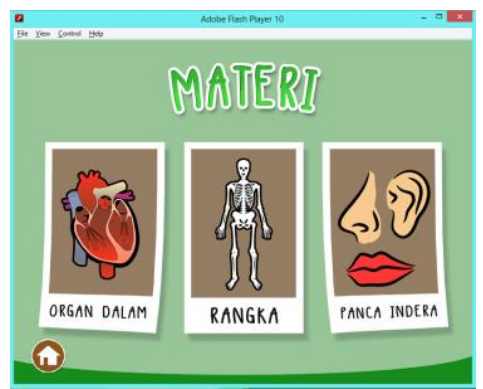

Gambar 24 Tampilan isi menu Materi Gambar 25.

Tampilan menu dari Rangka ditunjukkan oleh

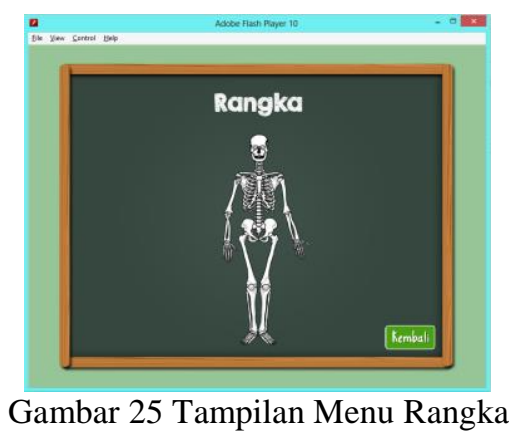

Untuk memilih materi Rangka maka dekatkan kursor dan klik pada bagian yang di blok biru. Setelah di klik maka akan ditampilkan penjelasan dalam bagian Rangka. Tampilan isi materi dari Rangka ditunjukkan oleh Gambar 26.

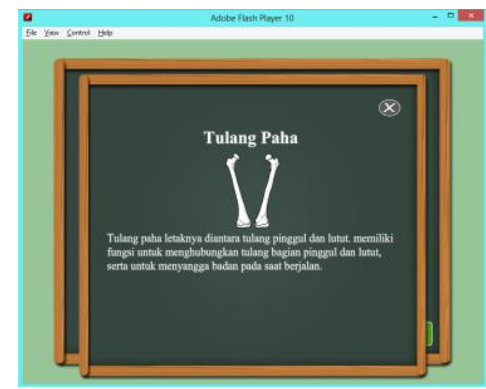

Gambar 26 Tampilan isi menu Rangka 
4. Tampilan menu Latihan Soal

Latihan soal yang diberikan berjumlah 10 soal bertipe pilihan ganda acak. Setiap 1 soal mempunyai 4 opsi jawaban, untuk menjawabnya pilihlah 1 jawaban yang paling tepat. Setelah memilih jawaban akan muncul pernyataan benar atau salah pada jawaban yang dipilih lalu klik tombol berikutnya. Jika belum memilih jawaban maka tombol berikutnya tidak akan berfungsi. Menu Latihan Soal ini diawali dengan pengisian nama kemudian untuk memulainya dilanjutkan dengan mengklik tombol Mulai. Setelah semua soal sudah terjawab maka muncul tampilan nilai yang berisi nama, jumlah soal benar, jumlah soal salah dan nilainya. Tampilan dari menu Latihan Soal ditunjukkan oleh Gambar 27 sampai 30.

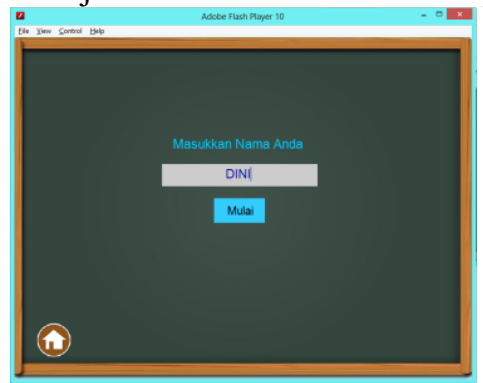

Gambar 17 Tampilan awal Latihan Soal

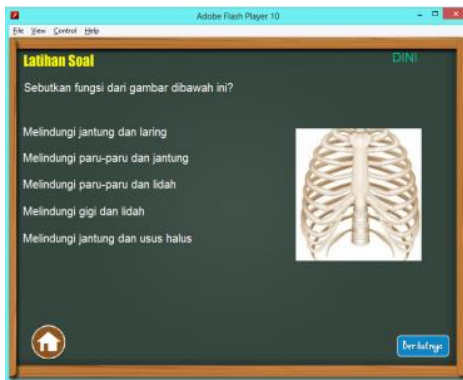

Gambar 28 Tampilan latihan soal pilihan ganda

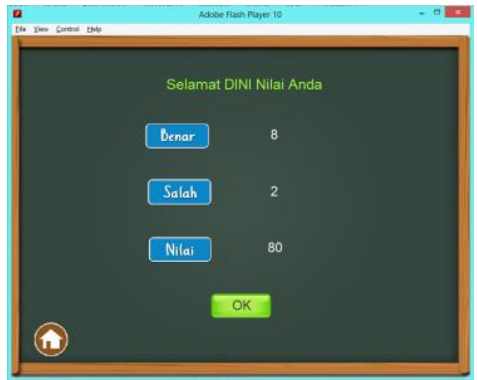

Gambar 29 Tampilan nilai hasil Latihan Soal

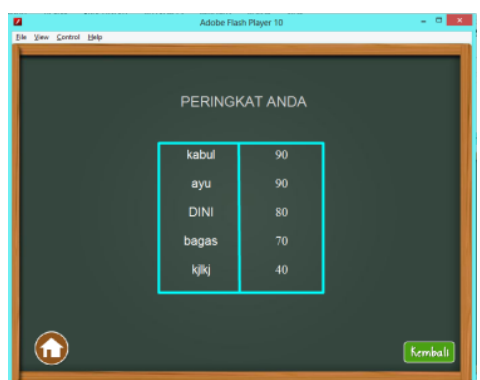

Gambar 30 Tampil peringkat nilai Latihan Soal
B. Pengujian Kotak Hitam

Pengujian ini dilakukan untuk menunjukkan fungsi program yang dibuat tentang cara operasi dan kegunaannya, apakah keluaran data sesuai dengan yang diharapkan. Pengujian ini dilakukan untuk mengetahui apakah masih terjadi kesalahan program atau program sudah berhasil diselesaikan dengan benar.

Pengujian aplikasi dibuat berupa tabel pengujian kotak hitam dari menu yang ada dalam aplikasi. Tabel pengujian pada menu secara keseluruhan ditunjukkan pada Tabel 1 .

Tabel 1 Tabel Pengujian aplikasi secara keseluruhan

\begin{tabular}{|c|c|c|c|}
\hline $\begin{array}{c}\text { Nama } \\
\text { Pengujian }\end{array}$ & $\begin{array}{c}\text { Bentuk } \\
\text { Pengujian }\end{array}$ & $\begin{array}{c}\text { Hasil yang } \\
\text { Diharapkan }\end{array}$ & $\begin{array}{c}\text { Hasil } \\
\text { Pengujian }\end{array}$ \\
\hline Loading & $\begin{array}{l}\text { Membuka } \\
\text { aplikasi }\end{array}$ & $\begin{array}{l}\text { Tampilan gambar- } \\
\text { gambar bagian tubuh } \\
\text { manusia, Edutomi, dan } \\
\text { menu. }\end{array}$ & Berhasil \\
\hline $\begin{array}{l}\text { Pengujian } \\
\text { menu } \\
\text { Standar } \\
\text { Kompetensi }\end{array}$ & $\begin{array}{l}\text { Mengklik } \\
\text { tombol menu } \\
\text { Standar } \\
\text { Kompetensi }\end{array}$ & $\begin{array}{l}\text { Tampil isi menu } \\
\text { Standar Kompetensi } \\
\text { dan Kompetensi Dasar }\end{array}$ & Berhasil \\
\hline $\begin{array}{l}\text { Pengujian } \\
\text { menu Materi }\end{array}$ & $\begin{array}{l}\text { Mengklik } \\
\text { tombol menu } \\
\text { Materi }\end{array}$ & $\begin{array}{l}\text { Tampil menu untuk } \\
\text { pemilihan materi } \\
\text { (organ dalam, rangka, } \\
\text { panca indera) }\end{array}$ & Berhasil \\
\hline $\begin{array}{l}\text { Pengujian } \\
\text { menu } \\
\text { Latihan Soal }\end{array}$ & $\begin{array}{l}\text { Mengklik } \\
\text { tombol menu } \\
\text { Latihan Soal }\end{array}$ & $\begin{array}{l}\text { Tampil nama untuk } \\
\text { memulai latihan soal }\end{array}$ & Berhasil \\
\hline $\begin{array}{l}\text { Pengujian } \\
\text { menu } \\
\text { Tentang }\end{array}$ & $\begin{array}{l}\text { Mengklik } \\
\text { tombol menu } \\
\text { Tentang }\end{array}$ & $\begin{array}{l}\text { Tampil isi menu } \\
\text { Tentang }\end{array}$ & Berhasil \\
\hline $\begin{array}{l}\text { Pengujian } \\
\text { tombol } \\
\text { Keluar }\end{array}$ & $\begin{array}{l}\text { Mengklik } \\
\text { tombol Keluar }\end{array}$ & Keluar dari aplikasi & Berhasil \\
\hline
\end{tabular}

Tabel 2 menunjukkan pengujian akan fungsi-fungsi yang dapat dijalankan pada menu Standar Kompetensi. Tabel 2 Tabel Pengujian Menu Standar Kompetensi

\begin{tabular}{|l|l|l|c|}
\hline \multicolumn{1}{|c|}{$\begin{array}{c}\text { Nama } \\
\text { Pengujian }\end{array}$} & Bentuk Pengujian & \multicolumn{1}{|c|}{$\begin{array}{c}\text { Hasil yang } \\
\text { Diharapkan }\end{array}$} & $\begin{array}{c}\text { Hasil } \\
\text { Pengujian }\end{array}$ \\
\hline $\begin{array}{l}\text { Pengujian } \\
\text { menu Standar } \\
\text { Kompetensi }\end{array}$ & $\begin{array}{l}\text { Mengklik menu } \\
\text { Standar } \\
\text { Kompetensi }\end{array}$ & $\begin{array}{l}\text { Tampil isi } \\
\text { Standar } \\
\text { Kompetensi dan } \\
\text { Kompetensi } \\
\text { Dasar }\end{array}$ & Berhasil \\
\hline $\begin{array}{l}\text { Pengujian } \\
\text { tombol Home }\end{array}$ & $\begin{array}{l}\text { Mengklik tombol } \\
\text { Home pada bagian }\end{array}$ & $\begin{array}{l}\text { Kembali ke } \\
\text { halaman } \\
\text { sebelumnya } \\
\text { (halaman menu } \\
\text { utama) }\end{array}$ & Berhasil \\
& & & \\
\hline
\end{tabular}


Menu Materi berisi materi-materi anatomi tubuh manusia, adapun fungsi-fungsi yang dapat dijalankan diuji dalam Tabel 3.

Tabel 3 Tabel Pengujian Menu Materi

\begin{tabular}{|c|c|c|c|c|c|c|c|}
\hline $\begin{array}{c}\text { Nama } \\
\text { Pengujian }\end{array}$ & $\begin{array}{c}\text { Bentuk } \\
\text { Pengujian }\end{array}$ & $\begin{array}{l}\text { Hasil yang } \\
\text { Diharapkan }\end{array}$ & $\begin{array}{c}\text { Hasil } \\
\text { Pengujian }\end{array}$ & $\begin{array}{l}\text { tombol } \\
\text { Home }\end{array}$ & $\begin{array}{l}\text { tombol home } \\
\text { pada bagian kiri } \\
\text { bawah }\end{array}$ & $\begin{array}{l}\text { halaman menu } \\
\text { utama }\end{array}$ & Berhasil \\
\hline $\begin{array}{l}\text { Pengujian } \\
\text { menu Materi }\end{array}$ & $\begin{array}{l}\text { Mengklik menu } \\
\text { Materi }\end{array}$ & $\begin{array}{l}\text { Tampil sub menu } \\
\text { untuk pemilihan } \\
\text { materi anatomi } \\
\text { tubuh manusia } \\
\text { (organ dalam. }\end{array}$ & Berhasil & $\begin{array}{l}\text { Pengujian } \\
\text { tombol } \\
\text { Keluar }\end{array}$ & $\begin{array}{l}\text { Mengklik } \\
\text { tombol keluar } \\
\text { pada bagian } \\
\text { kanan bawah. }\end{array}$ & Mengakhiri aplikasi & Berhasil \\
\hline
\end{tabular}

Pengujian terhadap fungsi-fungsi yang ada pada menu Latihan Soal ditunjukkan pada Tabel 4.

Tabel 4 Tabel Pengujian Menu Latihan Soal

\begin{tabular}{|l|l|l|c|}
\hline \multicolumn{1}{|c|}{$\begin{array}{c}\text { Nama } \\
\text { Pengujian }\end{array}$} & Bentuk Pengujian & \multicolumn{1}{|c|}{$\begin{array}{c}\text { Hasil yang } \\
\text { Diharapkan }\end{array}$} & $\begin{array}{c}\text { Hasil } \\
\text { Pengujian }\end{array}$ \\
\hline $\begin{array}{l}\text { Memulai } \\
\text { latihan soal }\end{array}$ & $\begin{array}{l}\text { Mengisikan nama } \\
\text { dan klik di kotak } \\
\text { Mulai }\end{array}$ & $\begin{array}{l}\text { Tampil soal pilihan } \\
\text { ganda no.1 }\end{array}$ & Berhasil \\
\hline $\begin{array}{l}\text { Pengujian } \\
\text { jawaban } \\
\text { latihan soal }\end{array}$ & $\begin{array}{l}\text { Mengklik salah } \\
\text { satu jawaban }\end{array}$ & $\begin{array}{l}\text { Tampil keterangan } \\
\text { jawaban benar atau } \\
\text { salah }\end{array}$ & Berhasil \\
\hline $\begin{array}{l}\text { Pengujian } \\
\text { hasil latihan } \\
\text { soal }\end{array}$ & $\begin{array}{l}\text { Menjawab soal } \\
\text { pilihan ganda } \\
\text { no.10 }\end{array}$ & $\begin{array}{l}\text { Tampil nama, } \\
\text { jumlah soal benar, } \\
\text { soal salah dan nilai }\end{array}$ & Berhasil \\
\hline $\begin{array}{l}\text { Pengujian } \\
\text { peringkat } \\
\text { nilai latihan } \\
\text { soal }\end{array}$ & $\begin{array}{l}\text { Mengklik tombol } \\
\text { OK ketika tampil } \\
\text { nilai latihan soal }\end{array}$ & $\begin{array}{l}\text { Tampil peringkat } \\
\text { nilai (10 nilai } \\
\text { tertinggi yang } \\
\text { ditampilkan) }\end{array}$ & Berhasil \\
\hline $\begin{array}{l}\text { Pengujian } \\
\text { tombol } \\
\text { Kembali }\end{array}$ & $\begin{array}{l}\text { Mengklik tombol } \\
\text { kembali pada } \\
\text { bagian kanan } \\
\text { bawah }\end{array}$ & $\begin{array}{l}\text { Kembali ke } \\
\text { halaman awal } \\
\text { latihan soal } \\
\text { (mengisi nama dan } \\
\text { klik tombol mulai) }\end{array}$ & Berhasil \\
\hline $\begin{array}{l}\text { Pengujian } \\
\text { tombol } \\
\text { Home }\end{array}$ & $\begin{array}{l}\text { Mengklik tombol } \\
\text { home pada bagian } \\
\text { kiri bawah }\end{array}$ & $\begin{array}{l}\text { Kembali ke } \\
\text { halaman } \\
\text { sebelumnya (menu } \\
\text { utama) }\end{array}$ & Berhasil \\
\hline
\end{tabular}

Pengujian terhadap fungsi-fungsi yang ada pada menu Tentang ditunjukkan pada Tabel 5.

Tabel 5 Tabel Pengujian Menu Tentang

\begin{tabular}{|l|l|l|c|}
\hline \multicolumn{1}{|c|}{$\begin{array}{c}\text { Nama } \\
\text { Pengujian }\end{array}$} & Bentuk Pengujian & \multicolumn{1}{|c|}{$\begin{array}{c}\text { Hasil yang } \\
\text { Diharapkan }\end{array}$} & $\begin{array}{c}\text { Hasil } \\
\text { Pengujian }\end{array}$ \\
\hline $\begin{array}{l}\text { Pengujian } \\
\text { menu } \\
\text { Tentang }\end{array}$ & $\begin{array}{l}\text { Mengklik menu } \\
\text { Tentang }\end{array}$ & $\begin{array}{l}\text { Tampil isi menu } \\
\text { Tentang }\end{array}$ & Berhasil \\
\hline $\begin{array}{l}\text { Pengujian } \\
\text { tombol home }\end{array}$ & $\begin{array}{l}\text { Mengklik tombol } \\
\text { home pada bagian } \\
\text { kiri bawah }\end{array}$ & $\begin{array}{l}\text { Kembali ke } \\
\text { halaman } \\
\text { sebelumnya } \\
\text { (halaman menu } \\
\text { utama) }\end{array}$ & Berhasil \\
\hline
\end{tabular}


Dari hasil pengujian aplikasi menggunakan metode uji kotak hitam (black-box testing) menunjukkan bahwa fungsi pada aplikasi telah berjalan sesuai dengan yang diharapkan. Hal ini ditampilkan oleh Tabel 1 hingga Tabel 5 yang menunjukkan hasil uji "Berhasil" pada tiap fungsi dan tombol dari aplikasi. Hal ini berarti bahwa secara fungsional, aplikasi ini telah berfungsi dengan baik dan telah menghasilkan keluaran yang diharapkan.

\section{PENUTUP}

\section{A. Kesimpulan}

Kesimpulan dari penelitian Tugas Akhir ini diantaranya sebagai berikut.

1. Aplikasi pembelajaran Anatomi Tubuh Manusia sebagai media pembelajaran interaktif untuk sekolah dasar telah berhasil dirancang dan dibangun menggunakan Flash dan dapat berjalan dengan ekstensi file .swf.

2. Berdasarkan hasil pengujian aplikasi menggunakan Uji Kotak Hitam (Black Box Test), seluruh fungsi menu yang ada dalam aplikasi telah berhasil sesuai dengan fungsinya masing-masing.

B. Saran

Saran yang diberikan dalam upaya pengembangan sistem yang lebih baik dikemudian hari diantaranya.

1. Aplikasi media pembelajaran yang dibuat hanya untuk materi pokok Anatomi tubuh manusia, dan masih bisa dikembangkan untuk pembuatan materi pelajaran yang lain.

2. Perlu dikembangkan penelitian lanjutan untuk mengembangkan aplikasi media pembelajaran anatomi tubuh manusia menjadi sistem pada perangkat bergerak atau dilengkapi dengan Augmented Reality (AR).

\section{DAFTAR PUSTAKA}

[1] Arifin, M., Strategi Belajar Mengajar Kimia Prinsip dan Aplikasinya Menuju Pembelajaran yang Efektif, Bandung: JICA, 2000.

[2] Azmiyawati, C., Ilmu Pengetahuan Alam untuk Kelas 5, Jakarta: Salingtemas, 2008.

[3] Binanto, Iwan., Multimedia Digital : Dasar Teori dan Pengembangannya, Yogyakarta: Andi, 2010.

/[4] Budiyono, S., Anatomi Tubuh Manusia, Bekasi-Jawa Barat: Laskar Aksara, 2011.

[5] Caterin, R., Aplikasi Multimedia Dalam Pembelajaran Teknologi Informasi dan Komunikasi (TIK) Materi Hardware Berbasis Flash Untuk Sekolah Menengah Atas. Tugas Akhir pada Prodi Sistem Komputer FT Undip., Semarang, 2014.

[6] Cahyana, Bisono Indra., Penggunaan Aplikasi Multimedia Pembelajaran Topologi Jaringan Komputer Berbasis Macromedia Flash untuk Meningkatkan Hasil
Belajar Mata Pelajaran TIK Siswa Kelas XI SMA N 1 Godean, 2013.

[7] Harjanto, A., Computer Assisted Instruction (CAI) Sebagai Media Pembelajaran Dalam Mata Pelajaran FIsika Sekolah Menengah Atas, Semarang, 2012.

[8] Luther, A. C., Authoring Interactive Multimedia, Boston: AP Professional, 1994.

[9] Maizora, S., Pembuatan Media Pembelajaran dengan Macromedia Flash 8, 2011.

[10] Pranowo, G., Kreasi Animasi Interaktif dengan Action Script 3.0 pada Flash CS5, Yogyakarta: C.V ANDI OFFSET, 2011.

[11] Puddya, Anggara P., Sejarah Perkembangan Adobe Flash, http://teknohere.com/, 24 Maret 2013.

[12] Rochim, L., Penerapan Pendekatan Jelajah Alam Sekitar pada Pembelajaran Struktur dan Fungsi Organ Manusia dan Hewan Berbantuan Multimedia Interaktif, Skripsi, Fakultas MIPA, UNNES., Semarang, 2008.

[13] Sadiman, A.S., Media Pendidikan, Jakarta: PT RajaGrafindo Persada, 2006.

[14] Suyanto, M., Multimedia Untuk Meningkatkan Keunggulan Bersaing, Yogyakarta: ANDI, 2005.

[15] Syaifuddin, Anatomi Tubuh Manusia untuk Mahasiswa Keperawatan, Jakarta: Salemba Medika, 2009.

[16] Tay, V., Multimedia Making it Work, Yogyakarta: CV ANDI OFFSET, 2006.

[17] Untari, V., Makalah Pendidikan Sebagai Ilmu Dalam Perspektif IPA, http://www.academia.edu/, 23 April.

[18] Yamin, M., Strategi Pemasaran Berbasis Kompetensi, Jakarta: Gaung Persada (GP) Press, 2010. 